\title{
Hubungan antara Kadar Low Density Lipoprotein dengan Tekanan Darah Sistolik saat Puncak Exercise pada Personil Kepolisian Daerah Sulawesi Tenggara
}

\section{(The Relationship between Low Density Lipoprotein Levels and Systolic Blood Pressure during Peak Exercise of Police Personnel in Southeast Sulawesi)}

\author{
Dina Fitriana ${ }^{1}$, Hilma Yuniar $^{2}$, Jamaluddin $^{3}$ \\ ${ }^{1}$ Program Pendidikan Dokter, Fakultas Kedokteran, Universitas Halu Oleo, Kendari \\ ${ }^{2}$ Bagian Patologi Klinik, Rumah Sakit Umum Daerah Kota Kendari \\ ${ }^{3}$ Fakultas Kedokteran, Universitas Halu Oleo, Kendari \\ Corresponding author e-mail: dr.jml99@gmail.com
}

\begin{abstract}
Background: Systolic blood pressure during exercise is the blood pressure as measured by aneroid sphygmomanometer at the peak exercise (treadmill), namely when the subject has experienced fatigue or heart rate has reached $>85 \%$ of Maximum Heart Rate. Purpose:This research purpose is to determine the relationship between LDL level and systolic blood pressure at the exercise peak of police personnel in Southeast Sulawesi. Methods: This research used analytical-observasional study with cross sectional aproach. The independent variables used in this research are LDL level while the dependent variables was systolic blood pressure during the peak exercise. Research location is in Maxima Laboratory Kendari.The subjects of this study were 95 people based on the inclusion and exclusion criteria that selected by Purposive Sampling method. Data collection was gained by taking the secondary data and was processed by using statistical test data of Independent T-test with a significance p-value <0.05. Result: The result of bivariate analysis showed that there was a relationship between LDL level and systolic blood pressure at the exercise peak on the police personnel in Southeast Sulawesi with a p-value =0,000 (<0.05). Conclusion: This study can be conlcuded that there was a relationship between LDL level and systolic blood pressure at the peak exercise of police personnel in Southeast Sulawesi.
\end{abstract}

Keywords: low density lipoprotein, systolic blood pressure, peak exercise.

\section{ABSTRAK}

Latar belakang : Puncak tekanan darah sistolik pada saat exercise adalah tekanan darah sistolik yang diukur dengan menggunakan sfignomanometer air raksa pada saat puncak exercise, dimana subyek sudah mengalami kelelahan atau denyut jantung telah mencapai $85 \%$ dari denyut jantung maximal. Tujuan: Tujuan penelitian ini adalah untuk mengetahui hubungan antara kadar LDL plasma dengan tekanan darah sistolik pada puncak exercise pada personil Kepolisian Daerah Sulawesi Tenggara. Metode: penelitian ini merupakan penelitian analitik-observasional dengan metode cross sectional. variabel independen adalah kadar LDL plasma dan dependen variabel adalah tekanan darah sistol pada puncak exercise. penelitian dilakukan di Laboratorium Klinik Maxima Kendari. sebanyak 95 sampel penelitian yang memenuhi kriteria inklusi dan eksklusi diambil dengan metode purposive sampling. Data tekanan darah saat puncak exercise dan kadar LDL plasma diambil dari data sekunder rekam medik pasien. Data kemudian dianalisa dengan uji statistik Independent T-test dan bermakna bila nilai $p<0,05$. Hasil: Analisa statistik menunjukkan adanya hubungan antara kadar LDL plasma dengan tekanan darah sistolik pada puncak exercise pada personil POLDA Sulawesi Tenggara, dengan nilai p=0,000. Simpulan : Pada penelitian ini dapat disimpulkan bahwa terdapat hubungan antara kadar LDL plasma dengan tekanan darah sistolik pada puncak exercise pada personil POLDA Sulawesi Tenggara.

Kata Kunci: low density lipoprotein, tekanan darah sistolik, puncak exercise 


\section{PENDAHULUAN}

Tekanan darah merupakan faktor yang dapat dipakai sebagai indikator untuk menilai sistem kardiovaskuler. Tekanan darah seseorang dipengaruhi oleh berbagai faktor di antaranya adalah usia, ras, jenis kelamin, stres, medikasi, aktivitas fisik. Dengan mengamati serta mempelajari pengaruh perubahan posisi tubuh dan aktivitas fisik terhadap tekanan darah, maka akan diperoleh gambaran mengenai kondisi sistem kardiovaskuler seseorang (Manembu dkk., 2015).

Aktivitas fisik merupakan salah satu faktor yang dapat mempengaruhi tekanan darah. Pada saat seseorang melakukan aktivitas fisik, maka tekanan darah akan meningkat. Peningkatan tekanan darah tersebut tergantung dari respon adaptasi sistem kardiovaskuler. Aktivitas fisik adalah seluruh kegiatan yang dapat meningkatkan penggunaan energi/kalori oleh tubuh. Latihan (exercise) merupakan serangkaian aktivitas yang terstruktur dan berirama dengan intensitas tertentu dalam jangka waktu tertentu yang bertujuan untuk meningkatkan kesegaran jasmani (Afriwardi, 2010).

Tekanan darah tinggi diakui sebagai faktor risiko utama untuk mortalitas penyakit kardiovaskuler (Deyanov, 2006). Penelitian yang dilakukan oleh Berger dkk., (2015) menyatakan bahwa tekanan darah saat exercise dapat digunakan untuk memprediksi perkembangan hipertensi sejak dini. Sebab, respon peningkatan tekanan darah merupakan salah satu indikator prognostik untuk menentukan diagnosis dini terkait risiko hipertensi (Kucukler, 2011).

Penelitian yang dilakukan oleh Kurl, dkk. (2001) menyatakan tekanan darah sistolik yang mengalami peningkatan maksimum 2 menit setelah latihan secara langsung mengalami risiko stroke. Bansal dan Ansari (2015) melakukan pengujian latihan treadmill, hasilnya menyatakan respon tekanan darah normal yang mengalami peningkatan pada saat treadmill berhubungan dengan peningkatan risiko hipertensi, kejadian kardiovaskuler, dan kematian. Kadar Low Density Lipoprotein (LDL) yang meningkat memiliki hubungan terhadap peningkatan tekanan darah sebesar 1,8 kali dari yang memiliki kadar LDL normal (Feryadi $d k k .$, 2012).

Polisi merupakan aparat negara yang memiliki peran penting dalam melindungi rakyat. Peran tersebut tentunya akan dilaksanakan dengan baik apabila didukung dengan kesehatan diri yang optimal, salah satunya adalah tekanan darah dan faktor-faktor yang mempengaruhinya, salah satunya adalah profil lipid. Oleh karena itu, peneliti tertarik untuk melibatkan polisi sebagai subjek penelitian. Profil lipid yang akan diteliti lebih lanjut adalah kadar LDL dalam darah dikaitkan dengan peningkatan tekanan darah pada saat exercise. Penelitian ini diharapkan berfungsi sebagai skrining awal terhadap anggota kepolisian yang berisiko menderita hipertensi. Selain itu, penelitian serupa masih jarang dilakukan dan di Indonesia belum ada data mengenai hubungan antara kadar LDL dengan tekanan darah sistolik pada saat puncak exercise. Oleh karena itu, peneliti tertarik meneliti tentang hubungan antara kadar LDL dengan tekanan darah sistolik pada saat puncak exercise.

\section{METODE PENELITIAN}

Jenis penelitian yang digunakan adalah penelitian analitik observasional 
dengan desain cross Sectional. Penelitian ini dilakukan pada bulan September 2018 di Laboratorium Swasta Kota Kendari (Laboratorium Maxima). Teknik pengambilan sampel dalam penelitian ini adalah purposive sampling dengan total sampel dalam penelitian ini adalah 95 orang.

Pengambilan data sekunder berupa usia, jenis kelamin, tekanan darah, kadar LDL, kadar HDL, kadar kolesterol total, dan trigliserida diperoleh dari dokumendokumen tertulis berupa data catatan rekam medik pasien pada saat pemeriksaan kesehatan personil POLDA di Laboratorium Maxima pada bulan April 2018.

Penelitian ini dilaksanakan setelah memenuhi persyaratan etik oleh Komisi Etik Penelitian Kesehatan Lembaga Penelitian dan Pengabdian Kepada Masyarakat Universitas Haluoleo Kendari, Nomor 2033/UN29.20/PPM/2018.

Penelitian ini melibatkan 95 personel POLDA Sulawesi Tenggara berjenis kelamin laki-laki yang melakukan pemeriksaan kesehatan rutin di Laboratorium Klinik MAXIMA Kendari. Berdasarkan Tabel 1 menunjukkan bahwa kelompok usia responden pada usia 20-30 tahun yaitu $4(4,2 \%)$ responden pada usia $31-40$ tahun yaitu $51(53,7 \%)$ responden pada usia 41-50 tahun yaitu $40(42,1 \%)$ responden. Jenis kelamin laki-laki 95 (100\%) responden. Sebanyak $26(27,4 \%)$ responden memiliki tekanan darah normal, sedangkan pre-hipertensi sebanyak 69 $(72,6 \%)$ responden. Sebanyak $22(23,2 \%)$ responden memeiliki LDL normal, sedangkan pada LDL berisiko yatu 73 $(76,8 \%)$ responden memiliki LDL yang tinggi atau beresiko. Sebanyak $79(83,2 \%)$ responden memiliki HDL normal, sedangkan $16(16,8 \%)$ responden memiliki HDL yang beresiko. Sebanyak 57 (60,0\%) responden memiliki level kolestrol normal, sedangkan 38 (40,0\%) responden memiliki level kolestrol total beresiko. Sebanyak 64 $(67,4 \%)$ responden memiliki kadar trigliserida normal, sedangkan 31 (32,6\%) responden memiliki kadar trigliserida beresiko.

Uji normalitas dalam penelitian ini menggunakan uji Kolmogorov-Smirnov Test. Didapatkan nilai signifikansi $(p)$ sebesar 0,264 yang berarti $(p)>0,05$, maka dapat disimpulkan bahwa nilai residual berdistribusi normal. Uji homogenitas pada penelitian ini menggunakan ANOVA. Diperoleh nilai signifikansi sebesar 0,398. Hal tersebut menunjukan bahwa $p=0,073>0,05$, maka dapat disimpulkan bahwa data berasal dari populasi yang homogen.

Berdasarkan hasil uji T-test Independent didapatkan nilai Sig. (2tailed $)=0,000$. Hal ini menunjukkan nilai $\operatorname{sig}(p)<0,05$ artinya Ha diterima dan Ho ditolak. Sehingga, dapat disimpulkan bahwa terdapat hubungan antara LDL dengan peningkatan tekanan darah sitolik pada puncak exercise personel kepolisian daerah Sulawesi Tenggara.

\section{HASIL}

Karakteristik sampel berdasarkan usia, tekanan darah sistolik awal, interpretasi kadar LDL, HDL, kolesterol total dan trigliserida ditunjukkan pada Tabel 1.

Hubungan antara Kadar LDL dengan Tekanan Darah Sistolik saat Puncak Exercise ditunjukkan pada tabel 2. 
Tabel 1. Distribusi Berdasarkan Karakteristik

\begin{tabular}{lcc}
\hline \multicolumn{1}{c}{ Karakteristik } & $\mathbf{n = 9 5}$ & Persentase (\%) \\
\hline Usia & 4 & 4,2 \\
20-30 tahun & 51 & 53,7 \\
31-40 tahun & 40 & 42,1 \\
$41-50$ tahun & & \\
\hline Tekanan Darah Sistolik Awal & 26 & 27,4 \\
Normal & 69 & 72,6 \\
Pre-Hipertensi & & \\
\hline LDL & 22 & 23,2 \\
Normal & 73 & 76,8 \\
Berisiko & & \\
\hline HDL & 79 & 83,2 \\
Normal & 16 & 16,8 \\
Berisiko & & \\
\hline Kolesterol Total & 57 & 60,0 \\
Normal & 38 & 40,0 \\
Berisiko & & 67,4 \\
\hline Trigliserida & 64 & 32,6 \\
Normal & 31 & \\
Berisiko & & \\
\hline
\end{tabular}

Tabel 2. Hubungan antara Kadar LDL dengan Tekanan Darah Sistolik saat Puncak Exercise pada Personel Kepolisian Daerah Sulawesi Tenggara

\begin{tabular}{ccc}
\hline Kriteria LDL & Rerata Tekanan Darah Sistolik (mmHg) & p-value \\
\hline Normal & 136,82 & 0,000 \\
\hline Berisiko & 148,08 & 0,000 \\
\hline
\end{tabular}

\section{PEMBAHASAN}

Penelitian ini dilakukan untuk melihat hubungan antara kadar LDL dengan peningkatan tekanan darah sitolik saat puncak exercise. Hasil penelitian menunjukkan bahwa terdapat hubungan antara kadar LDL plasma dengan peningkatan tekanan darah sitolik pada puncak exercise personel Kepolisian Daerah Sulawesi Tenggara $(p=0,000)$. Tekanan darah seseorang dipengaruhi oleh berbagai faktor di antaranya adalah usia, ras, jenis kelamin, stress, medikasi, dan aktivitas fisik (Manembu $d k k ., 2015$; Siera, dkk., 2010; Sabbahi dkk., 2018).

Pada saat seseorang melakukan aktivitas fisik (Exercise) otomatis curah jantung meningkat, peningkatan aliran darah ini diperlukan untuk menyalurkan nutrien tambahan ke otot yang sedang bekerja dan untuk membuang produk sampingan kontraksi otot. Faktor vasodilator meningkatkan aliran darah otot sewaktu olahraga. Kontraksi otot meningkatkan laju metabolik jaringan ini, yang pada gilirannya menurunkan konsentrasi oksigen di jaringan, penurunan konsentrasi oksigen menyebabkan pembuluh darah melebar. Perubahan kardiovaskular sewaktu olahraga menyalurkan lebih banyak nutrien dan membuang lebih banyak produk sampingan metabolik dari otot yang berolahraga. Sehingga perubahan ini 
menyebabkan banyak perubahan yang pada akhirnya menyebabkan meningkatnya tekanan arteri rerata, suatu akibat penting dari peningkatan aktivitas simpatis sewaktu olahraga. Penyebab meningkatnya tekanan ini adalah konstriksi arteriol dan arteri kecil, meningkatnya kontraktilitas jantung, dan meningkatnya tekanan pengisian sistemik rerata (Hall, 2007).

Selain itu, tekanan darah juga dapat dipengaruhi oleh kadar LDL. Kolesterol LDL merupakan jenis kolesterol berbahaya sehingga sering juga disebut kolesterol jahat. Kolesterol LDL mengangkut kolesterol paling banyak dalam darah. LDL yang berlebihan dalam darah akan mudah melekat pada dinding sebelah dalam pembuluh darah dan akan menembus dinding pembuluh darah melalui lapisan sel endotel, masuk ke lapisan intima dan mengalami oksidasi, sehingga terbentuk LDL yang teroksidasi. LDL teroksidasi akan memacu terbentuknya zat yang dpat melekatkan dan menarik monosit menembus lapisan endotel dan masuk ke dalam intima. LDL yang teroksidasi akan mengalami oksidasi tahap kedua menjadi LDL yang teroksidasi sempurna yang dapat mengubah makrofag menjadi foam cell. Foam cell yang akan membentuk benjolan yang mengakibatkan penyempitan lumen, sehingga pembuluh darah menjadi sempit dan aliran darah kurang lancar. Foam cell menyebabkan terbentuknya lapisan lemak pada endotel dan berkembang menjadi aterosklerosis apabila kadar LDL tetap tinggi dan mengakibatkan tingginya resistensi vaskular sistemik dan memicu peningkatan tekanan darah (Isselbacher $d k k ., 1995)$.

Kadar LDL yang tinggi merupakan salah satu faktor resiko terjadinya hipertensi dimasa mendatang. Peningkatan tekanan saat exercise juga terbukti sebagai predictor akan terjadinya hipertensi dimasa mendatang. Penelitian yang dilakukan oleh Feryadi (2012) bahwa kadar LDL yang meningkat memiliki hubungan terhadap peningkatan tekanan darah sebesar 1,8 kali dari yang memiliki kadar LDL normal. Penelitian yang dilakukan oleh Berger $d k k$. (2015) menunjukkan bahwa tekanan darah saat exercise dapat digunakan untuk memprediksi perkembangan hipertensi sejak dini.

Penelitian oleh Bansal dan Ansari (2015), Sharabi $d k k$. (2001) dan Musial dkk. (2016) juga menunjukkan bahwa respon tekanan darah yang mengalami peningkatan pada saat exercise (treadmill) berhubungan dengan peningkatan risiko hipertensi kedepannya, kejadian kardiovaskuler dan kematian. Kemudian penelitian yang dilakukan oleh Kucukler dkk. (2011) dan Kim \& Ha (2016) menyatakan respon peningkatan tekanan darah merupakan salah satu indikator prognostik untuk menentukan diagnosis dini terkait risiko hipertensi. Penelitian yang sama yang dilakukan oleh Kurl $d k k$. (2001) menyatakan tekanan darah sistolik yang mengalami peningkatan maksimum 2 menit setelah latihan, secara langsung mengalami risiko stroke.

\section{SIMPULAN}

Terdapat hubungan antara kadarLDL plasma dengan peningkatan tekanan darah sitolik pada puncak exercise personel Kepolisian Daerah Sulawesi Tenggara.

\section{SARAN}

Diharapkan pada personil POLDA Sulawesi Tenggara untuk dapat mengendalikan faktor-faktor resiko 
hipertensi, terutama pada mereka yang memiliki kadar LDL plasma yang tinggi dan terjadi peningkatan tekanan darah pada puncak exercise karena hal tersebut telah terbukti menjadi resiko untuk kejadian hipertensi dimasa mendatang.

\section{DAFTAR PUSTAKA}

Afriwardi. 2010. Ilmu Kedokteran Olahraga. Jakarta: Buku Kedokteran EGC.

Bansal, S., Ansari, H.A. 2015. Clinical significance of blood pressure levels durring treadmill exercise testing. Hypertension Journal. 1(2): 83-87.

Berger, A., Grossman, E., Katz, M., Kivity, S., Klempfner, R., Segev, S, $d k k$. 2015. Exercise Blood Pressure And The Risk For Future Hypertension Among Normotensive Middle-Aged Adult. American Health Association.

Deyanov, C., Vangelova, K. Blood Pressure Response To Exercise Test And Serum Lipids In Normotensive Men With Positive Family History Of Hypertension. Cent Eur J Publ Health. 14 (4): 186-188.

Feryadi, R., Sulastri, D., Kadri, H. 2012. Hubungan Kadar Profil Lipid dengan Kejadian Hipertensi pada Masyarakat Etnik Minangkabau di Kota Padang. Jurnal Kesehatan Andalas. 3(2).

Hall, J.E. 2007. Guyton \& Hall Buku Saku Fisiologi Kedokteran. Edisi 11. Jakarta : EGC.

Isselbacher, K.J., Braunwald, E., Wilson, J.D., Martin, J.B., Fauci, A.S., Kasper, D.L. 1995. Harrison's Principles of Internal Medicine. Edisi 13. Terjemahan Asdie, A.H. 2013. Harrison Prinsip-Prinsip Ilmu Penyakit Dalam. Edisi 13. Volume 5. Jakarta: EGC.

Kim, D., dan Ha, J. 2016. Hypertensive response to exercise: mechanisms and clinical implication. Clinical Hypertension. 22:17.

Kucukler, N., Yalcin, F., Abraham, P.T., Garcia, J.M. 2011. Stress induced hypertensive response: should it be evaluated more carefully. http://www.cardiovascularultrasoun d.com/content/9/1/22.

Kurl, S., Laukkanen, A.J., Rauramaa, R., Lakka, A.T., Sivenius, J., Salonen T.J. 2001. Systolic Blood Pressure Response to Exercise Stress Test and Risk of Stroke. Stroke. 32:20362041.

Manembu, M., Rumampuk, J., Danes, V. R. 2015. Pengaruh Posisi Duduk dan Berdiri Terhadap Tekanan Darah Sistolik dan Diastolik pada Pegawai Negeri Sipil Kabupaten Minahasa Utara. Jurnal e-Biomedik (eBm) 3(3): 815.

Musial, K.W., dkk. 2016. Blood Pressure Response to Submaximal Exercise Test in Adults. BioMed Research International.

Sabbahi, A., $d k k$. 2018. Peak Blood Pressure Responses During Maximum Cardiopulmonary Exercise Testing. Hypertension. 71:229-236.

Sharabi, Y., Ben-Cnaan, R., Hanin, A., Martonovitch, G., Grossman, E. 2001. The Significance of Hypertensive Response to Exercise as a Predictor of Hypertension and Cardiovascular Disease. $J$ Hum Hypertens. 15(5):353-6.

Siera, M.C., dkk. 2010 Blood pressure response to exercise testing. Apunts Med Esport. 45(167):191-200. 